\title{
Studi Kandungan Kimia Ekstrak Buah Pakoba Merah (Syzygium sp)
}

\author{
Jenny Kumajas ${ }^{a}$, Dian Herlinda Octorina Howan*a \\ a Jurusan Kimia, Fakultas MIPA, Universitas Negeri Manado, Tondano, 95618, Indonesia
}

\begin{tabular}{l} 
I N F O A R T I K E L \\
\hline Diterima 16 Oktober 2018 \\
Disetujui 30 Oktober 2018 \\
\\
\hline Key word: \\
Red pakoba (Syzygium sp) \\
Phytochemical screening \\
Secondary metabolite compound \\
\hline Kata kunci: \\
Pakoba merah (Syzygium sp) \\
Skrining fitokimia \\
Senyawa metabolit sekunder \\
\hline
\end{tabular}

*e-mail:dianhowan@unima.ac.id ${ }^{*}$ Telp:082189396146

\begin{abstract}
A BSTRACT
Red Pakoba (Syzygium sp) is a plant endemic to North Sulawesi. This study aims to find secondary metabolites from red pakoba fruit extract (Syzygium sp). The process is carried out by extraction and phytochemical testingFrom the phytochemical filtration results obtained the extract of red Pakoba fruit contains phenol compounds, terpenes, steroids and flavonoids. It needs further investigation the activity and the structure of the active compound from red pakoba fruit extract.
\end{abstract}

\begin{abstract}
A B STRAK
Pakoba Merah (Syzygium sp) merupakan tumbuhan endemik daerah Sulawesi Utara. Penelitian ini bertujuan untuk mengidentifikasi kandungan senyawa metabolit sekunder dari ekstrak buah pakoba merah (Syzygium sp). Proses identifikasi dilakukan dengan ekstraksi dan uji fitokimia Dari hasil screening fitokimia didapatkan hasil ekstrak buah Pakoba merah mengandung senyawa fenol, terpen, steroid dan flavonoid. Selanjutnya perlu dilakukan penelitian untuk mengetahui secara jelas aktivitas dan struktur senyawa aktif dari ektrak buah pakoba merah.
\end{abstract}

\section{Pendahuluan}

Pakoba merah merupakan salah satu tumbuhan dengan status endemik Sulawesi Utara yang banyak dimanfaatkan secara tradisional oleh masyarakat Minahasa, suku lokal di daerah Sulawesi Utara [1]. Pakoba merah termasuk dalam genus Syzygium yang beberapa jenisnya belum diketahui spesiesnya, serta belum banyak penelitian mengenai kandungan senyawa dalam tumbuhan Pakoba merah. Secara umum genus Syzygium mengandung metabolit sekunder berupa flavonoid, alkaloid, tanin dan terpenoid yang digunakan di dalam dunia pengobatan antara lain untuk anti radang, penahan rasa sakit dan anti jamur [2].

Terdapat laporan yang menyebutkan potensi kelompok Syzygium. Aktivitas hipoglicemik (menurunkan kadar gula darah) dari biji Syzygium cumini [3]. Buah Syzygium cumini mengandung senyawa 5,7,4'-trihidroksiflavan [4]. Daun Syzygium cumini mengandung lupeol, yang merupakan senyawa golongan steroid yang berpotensi antidiabetes [5] dan quercetin [6]. Ekstrak n-heksan daun pakoba merah mengandung senyawa triterpenoid $\beta$ amirin yang berpotensi antimikroba [7], sementara ekstrak butanol mengandung isoflavon dan flavon yang berpotensi antioksidant [8]. Sehubungan dengan banyaknya potensi kandungan senyawa yang 
terdapat dalam buah Pakoba merah, maka perlu dilakukan eksplorasi terhadap kandungan senyawa metabolit sekunder khususnya pada ekstrak buah pakoba merah yang memiliki potensi untuk dijadikan sebagai obat.

\section{Bahan dan Metode}

Sampel tumbuhan yang digunakan adalah buah pakoba merah segar yang diambil dari Desa Laikit Kabupaten Minahasa Utara. Pelarut yang digunakan meliputi: aqudes, etanol $70 \%$ dan pelarut teknis: n-heksan, etil asetat, butanol dan metanol yang telah didestilasi ulang. Untuk skrining fitokimia, bahan yang digunakan adalah larutan kloroform amoniak, larutan asam sulfat, pereaksi Reagen Wagner, pereaksi Mayer, Pereaksi Dragendorff, larutan $\mathrm{NaOH} 10 \%$, larutan besi (III) klorida 10\%, larutan kloroform, larutan asam klorida,

Peralatan yang digunakan berupa alatalat gelas meliputi: gelas kimia, gelas ukur, erlenmeyer, corong, pipet, chamber, pengaduk dan corong pisah, toples, blender, kolom kromatografi, vial. Seperangkat alat penguap putar (Rotavapour Butchi), seperangkat alar redestilasi, dan alat lainnya seperti corong buchner, neraca analitik, oven, hot plate, spatula, pinset, gunting, mistar, dan pensil.

\section{Prosedur Penelitian}

Preparasi Sampel

Buah pakoba dipilih yang berwarna merah tua, segar, tidak berlubang dan tidak memiliki bercak-bercak. Buah pakoba merah dipetik, dicuci, ditimbang kemudian dihaluskan dengan blender.

\section{Ektraksi dan Isolasi Senyawa}

Metode isolasi dan identifikasi kandungan metabolit sekunder dalam penelitian ini didasarkan pada penelitian [9]. Sampel buah pakoba merah dihaluskan dengan cara diblender, kemudian dimaserasi menggunakan pelarut etanol yang kadarnya $70 \%$, didiamkan 24 jam hingga diperoleh filtrat yang kemudian disaring. Maserasi dilakukan selama beberapa kali sampai filtrat yang dihasilkan jernih. Filtrat yang diperoleh ditampung kemudian dievaporasi hingga diperoleh ekstrak kental etanol. Ekstrak kental etanol kemudian diuji kandungan kimianya menggunakan skrining fitokimia.

\section{Partisi}

Ekstrak kental etanol ditimbang sebanyak 50 gr, dilarutkan dalam $250 \mathrm{~mL}$ aquades, selanjutnya dipartisi berturut-turut menggunakan n-heksan (13 x $300 \mathrm{~mL})$, etil asetat $(15 \times 300 \mathrm{~mL})$ dan butanol $(19 \times 300 \mathrm{~mL})$. Filtrat dievaporasi dan ditimbang sehingga diperoleh ekstrak fraksi n-heksan, etil asetat, butanol dan fraksi air.

\section{Skrinning Fitokimia}

1. Uji Fenolik

Sebanyak 1 gram ekstrak buah pakoba merah ditambahkan beberapa tetes larutan besi klorida $\left(\mathrm{FeCl}_{3}\right)$ 1\%. Bila ekstrak mengandung senyawa fenolik, akan terjadi perubahan warna [10].

2. Uji Tanin

Sebanyak $1 \mathrm{~g}$ ekstrak ditambahkan dengan beberapa tetes larutan timbal asetat $\left(\mathrm{Pb}\left(\mathrm{C}_{2} \mathrm{H}_{3} \mathrm{O}_{2}\right)_{2}\right) 1 \%$. Jika terjadi warna biru tua atau hitam kehijauan menunjukkan adanya tannin [10].

3. Uji Saponin

Sebanyak 2-3 mL ekstrak dimasukkan ke dalam tabung reaksi, kemudian ditambahkan $5 \mathrm{~mL}$ air panas lalu didinginkan, kemudian dikocok kuat-kuat selama 10 detik lalu ditambahkan 1 tetes $\mathrm{HCl} 2 \mathrm{~N}$. Uji positif ditunjukkan dengan terbentuknya buih yang stabil setinggi 1-10 $\mathrm{cm}$ selama tidak kurang dari 10 menit [10].

4. Uji Steroid dan Triterpenoid

Sebanyak 2 g ekstrak ditambahkan dengan kloroform \& air (1:1) kemudian ekstrak kloroform diteteskan pada plat tetes sebanyak 2 tetes lalu dibiarkan sampai kering, kemudian ditambahkan asam sulfat pekat dan dibiarkan selama beberapa menit. Adanya steroid ditunjukan oleh warna biru atau hijau sedangkan triterpenoid memberikan warna merah atau ungu [11].

5. Uji Flavonoid

Sebanyak 2 g ekstrak ditambahkan dengan metanol sebanyak $5 \mathrm{~mL}$, kemudian disaring dan dibagi 2 bagian. Tabung A 
ditambahkan $\mathrm{H} 2 \mathrm{SO} 4 \mathrm{NaOH} 10 \%$ sebanyak 2 tetes, sementara tabung B ditambahkan $\mathrm{NaOH} 10 \%$. Kedua tabung dikocok. Uji positif ditunjukan dengan terbentuknya warna merah, kuning, atau jingga [11].

\section{Hasil dan Pembahasan}

Buah pakoba merah sebanyak 2,92 Kg dimasaresi selama 7×24 jam menghasilkan filtrat sebanyak 10, 927 liter. Filtrat kemudian dievaporasi dan menghasilkan ekstrak kental etanol sebanyak 258, $61 \mathrm{gr}$.

Ekstrak kental etanol ditimbang sebanyak $50 \mathrm{gr}$, dilarutkan dalam $250 \mathrm{~mL}$ aquades, selanjutnya dipartisi berturut-turut menggunakan n-heksan (13 x $300 \mathrm{~mL})$, etil asetat $(15 \times 300 \mathrm{~mL})$ dan butanol $(19 \times 300 \mathrm{~m}$

L). Filtrat dievaporasi dan ditimbang sehingga diperoleh ekstrak fraksi n-heksan, etil asetat, butanol dan fraksi air seperti yang ditampilkan dalam Tabel 1.

Tabel 1. Hasil partisi ekstrak kental etanol buah pakoba merah

\begin{tabular}{cc}
\hline Fraksi & Berat (gr) \\
\hline n-heksan & 1,35 \\
Etil Asetat & 5,83 \\
Butanol & 9,33 \\
Air & 30,04 \\
\hline
\end{tabular}

\section{Skrinning Fitokimia}

Skrining fitokimia merupakan cara sederhana untuk melakukan analisis kualitatif kandungan senyawa yang terdapat dalam tumbuhan. Pada percobaan ini tanaman atau bagian tanaman yang akan digunakan yakni buah pakoba merah yang telah dihaluskan. Tujuan melakukan skrining fitokimia pada buah pakoba ini yakni untuk mengetahui apakah buah pakoba ini mengandung senyawa Fenolik, Tannin, saponin, Steroid, dan Flavonoid. Sebelum melakukan skrining fitokimia sampel buah pakoba merah dihaluskan sampai ekstra kental terlebih dahulu hal ini bertujuan untuk menghancurkan dinding sel yang sifatnya kaku sehingga senyawa target (metabolic sekunder) yang berada dalam vakuola mudah diambil dan memudahkan dalam pengujian.

1. Uji fenolik

Senyawa fenolik meliputi bermacam senyawa yang memiliki ciri yaitu berupa senyawa aromatis. Beberapa senyawa yang termasuk dalam golongan fenolik antara lain fenol sederhana, lignin, antrakinon, flavonoid, tannin dan fenil propanoid. Fenol sederhana memiliki kelarutan yang terbatas dalam air dan bersifat asam. Pada uji fenolik ini masingmasing sampel yang sudah dimasukan dalam tabung di ekstraksi dengan metanol, ini dimaksudkan agar senyawa- senyawa polar yang terkandung dalam sampel larut dalam metanol yang juga bersifat polar. Setelah itu disaring dengan menggunakan kapas agar larutan sampel dapat dipisahkan filtrat dan ampasnya sehingga jelas untuk diamati perubahan warnanya.

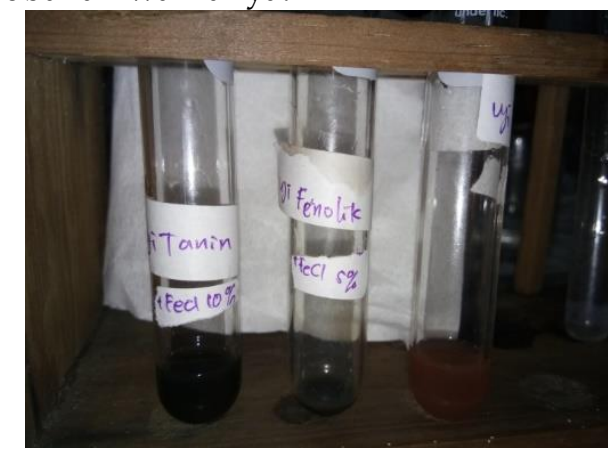

Gambar 1. Hasil Uji Fenolik. Larutan sampel buah pakoba saat ditambahkan $\mathrm{FeCl}_{3} 1 \%$ sebanyak 2-3 tetes maka larutan berubah warna dari merah kehitaman menjadi biru kehitaman tetapi tidak terlalu gelap jadi larutan sampel buah pakoba ini positif $1(+)$ mengandung senyawa fenolik.

Senyawa fenol merupakan senyawa aromatik yang memiliki satu gugus hidroksi. Karena gugus aromatis yang dimilikinya, fenol dapat melakukan resonansi yaitu perputaran awan elektron disekitar cincin fenol. Kemampuan resonansi ini yang menyebabkan fenol cukup reaktif dalam identifikasinya dan dapat memancarkan warna tertentu yang berbeda. Pada saat fenol direaksikan dengan $\mathrm{FeCl}_{3}$ pada pelat tetes terjadi perubahan warna yang cukup signifikan. Contoh pada senyawa fenol yaitu resinol, hal ini terjadi karena gugus hidroksi yang dimiliki oleh resorsinol terpecah dan bereaksi dengan $\mathrm{Fe}^{3+}$.

2. Uji Tannin

Tannin merupakan senyawa polifenol yang berarti termasuk dalam senyawa fenolik. Pada uji tanin ini sampel di ekstraksi dengan 
air panas, pemanasan ini berfungsi untuk melarutkan tanin agar terpisah dari bagian tubuh tumbuhan sampel. Kemudian disaring dengan kapas untuk memisahkan filtrat dengan ampasnya.

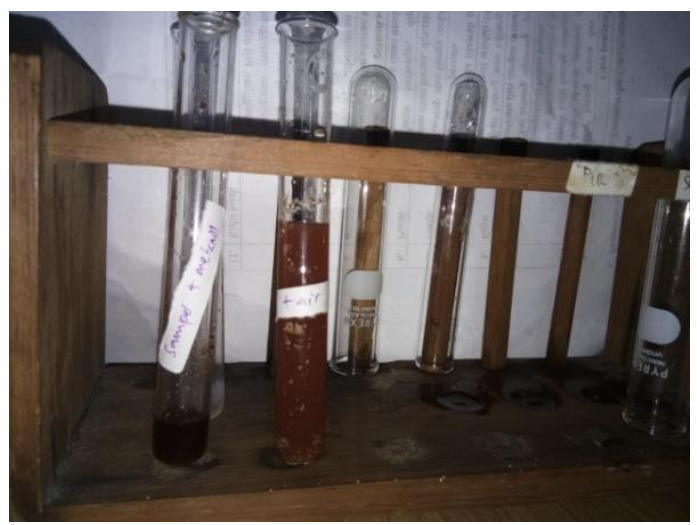

Gambar 2. Hasil uji Tannin. Larutan sampel buah pakoba saat ditambahkan $\mathrm{Pb}\left(\mathrm{C}_{2} \mathrm{H}_{3} \mathrm{O}_{2}\right)_{2}$

1\%sebanyak 2-3 tetes maka larutan tidak berubah warna menjadi hijau kehitaman melainkan berubah warna menjadi merah bata, jadi larutan sampel buah pakoba ini negaitif (-) mengandung senyawa tannin.

\section{Uji Saponin}

Saponin merupakan senyawa yang menimbulkan busa jika dikocok dalam air. Sampel di ekstraksi dengan air panas, pemanasan ini berfungsi untuk melarutkan saponin agar terpisah dari bagian tubuh tumbuhan sampel. Kemudian disaring dengan kapas untuk memisahkan filtrat dengan ampasnya.

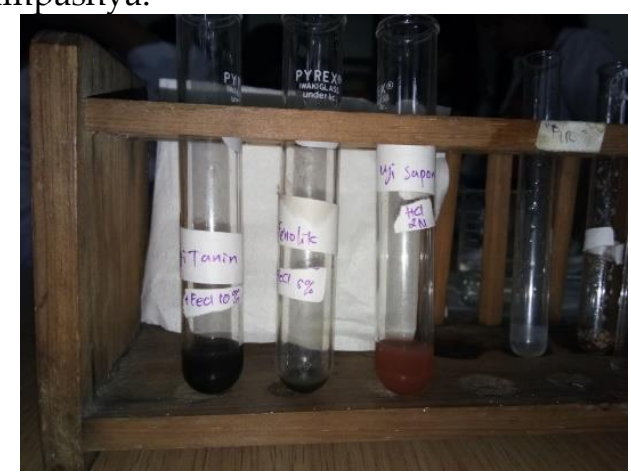

Gambar 3. Hasil Uji Saponin. Larutan sampel buah pakoba saat ditambahkan $\mathrm{HCl}$

$2 \mathrm{~N}$ sebanyak 2 tetes maka larutan ini setelah dikocok selama 10 menit tidak membentuk buih sehingga larutan sampel buah pakoba ini ( - ) tidak mengandung senyawa saponin.
4. Uji Lieberman Buchard ( uji terpen dan steroid)

Pada uji ini sampel diekstraksi dengan etanol, kemudian disaring dengan kapas untuk memisahkan filtrat dengan ampasnya. Setelah dipanaskan sampai kering, ekstrak ditambahkan kloroform dan air dengan perbandingan 1: 1 . Diambil ekstrak kloroformnya lalu ditambahkan asam sulfat pekat. Sampel (+) bila mengalami perubahan warna merah atau cokelat mengandung terpenoid (triterpen) dan warna biru, ungu atau hijau mengandung steroid.

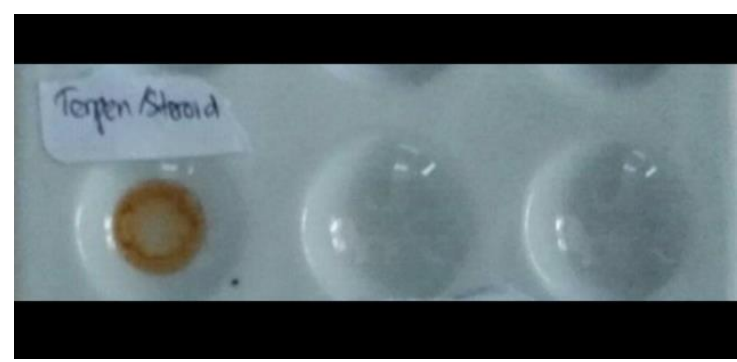

Gambar 4. Hasil Uji Terpen dan Steroid.

Larutan sampel buah pakoba positif (+) mengandung terpenoid (triterpen) karena perubahan warna dan steroid karena menghasilkan perubahan warna merah atau cokelat dan biru, ungu atau hijau.

\section{Uji Flavonoid}

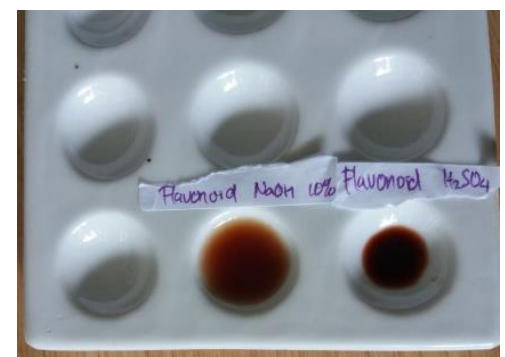

Gambar 5. Hasil Uji Flavonoid. Larutan sampel buah pakoba untuk tabung A (+) untuk tabung $\mathrm{B}(+)$

Pada uji flavonoid sampel yang sudah dihaluskan dengan mortar diekstraksi dengan metanol dengan tujuan mengekstrak senyawa yang diduga mengandung flavonoid kemudian larutan dibagi menjadi dua dan dimasukan dalam tabung $\mathrm{A}$ dan tabung B. Tabung A ditambahkan $\mathrm{H}_{2} \mathrm{SO}_{4}$ 
sebanyak $2 \mathrm{ml}$ dan Sampel + mengandung flavonoid bila terjadi perubahan warna yang sangat mencolok (kuning, merah atau cokelat) sedangkan pada tabung B ditambahkan $\mathrm{NaOH} 10 \%$.

\section{Ucapan terimakasih}

Diucapkan terima kasih kepada Direktorat Riset dan Pengabdian Masyarakat (DRPM) Kementerian Riset, Teknologi dan Pendidikan Tinggi (Kemenristekdikti) Republik Indonesia yang telah mendanai penelitian ini melalui skim Penelitian Dosen Pemula (PDP). Diucapkan juga terima kasih kepada Lembaga Penelitian dan Pengabdian Masyrakat (LPPM) Universitas Negeri Manado yang telah memfasilitasi pelaksanaan dan pelaporan hasil penelitian ini.

\section{Kesimpulan}

Berdasarkan hasil penelitian ditemukan bahwa dalam ekstrak buah Pakoba Merah mengandung senyawa metabolit sekunder jenis fenolik, terpenoid, steroid, dan flavonoid.

\section{Daftar Pustaka}

1. Nurrani, L., Tabba., S. Sifat Fisis Mekanis Kayu Pakoba dan Penggunaannya sebagai Jenis Endemik Lokal Sulawesi Utara. 2012. Manado ; Balai Penelitian Kehutanan Manado.

2. Mahmoud, I., Marzouk, M., Moharram, M., El-Gindi, M., Hassan, A. Acylated Flavonol Glycosides from Eugenia jambolana Leaves. Phytochemistry. 2001. 58. 1239-1244.

3. Kumar, A.R., Ilavarasan, T.J., M. Deecaraman., P. Aravindan, P., M. R. V.Krishan. Anti-diabetic Activity of Syzygium cumini and Its Isolated Compound Against Streptozotocininduced Diabetic Rats. Journal of Medicinal Plants Research 2008.Vol. 2(9), 246-249.

4. Swami, S.B., Thakor, N.S.J., Patil, M.M., Haldankar, P.M. Jamun (Syzygium Cumini (L.) A Review of It's Food and Medicinal Uses. Journal of Scientific Research : Food and Nutrition Sciences. 2012.,3, 1100-1117.

5. Alam, Md. R., Rahman, A. B. Moniruzzaman, Md., Kadir, Md. F., Haque, Md. A., Alvi, Md. R., Ratan, Md. Evaluation of Antidiabetic Phytochemicals in Syzygium cumini (L.) Skeels (Family: Myrtaceae). Journal of Applied Pharmaceutical Science. 2012.Vol. 2 (10) 094-098.

6. Ayyanar, M., Babu, P.S. Syzygium cumini (L.) Skeels : A Review of It's Phytochemical Constituents and Traditional Uses. Asian Pacific Journal of Tropical Biomedicine. 2012. 10.1016/S2221-1691(12)60050-1.

7. Paat, V. Senyawa Berpotensi Anti Mikroba dari Daun Pakoba Merah (Syzygium sp). Skripsi. 2011.Tondano; Universitas Negeri Manado.

8. Aloanis, A.A. Senyawa Berpotensi Anti Oksidant dari Daun Pakoba Merah (Syzygium sp).Skripsi. 2011. Tondano; Universitas Negeri Manado.

9. Rumampuk, R. J. Potensi Antioksidan dan Anti Diabetes dari Kelompok Tumbuhan Syzygium sp Asal Sulawesi Utara. 2014. Laporan Hibah Kompetensi. Jakarta ; DIKTI.

10. Al-Maliki, A.D.M., Isolation and identification of phenolic compounds from Elletaria cardamomum seeds and study of their medicinal activity against pathogenic bacteria of prostat gland. Journal of Missan researches. 2011.8 (15).

11. Harborne, J.B., Phytochemical methods. A guide to modern techniques of plant analysis. 1987. Chapman and Hall, London 